\title{
Perceptions and Attitudes towards Blended Learning for English Courses: A Case Study of Students at University of Bisha
}

\author{
Mohammed Mohammed Nasser Hassan Ja'ashan ${ }^{1}$ \\ ${ }^{1}$ English Department, College of Arts and Sciences, Bisha, University of Bisha, Saudi Arabia \\ Correspondance: Mohammed Mohammed Nasser Hassan Ja'ashan, English Department, College of Arts and \\ Sciences, Bisha, University of Bisha, Saudi Arabia. Tel: 966-532-889-348. E-mail: suhaib1998@yahoo.com
}

Received: June 26, 2015 Accepted: August 8, 2015 Online Published: August 11, 2015

doi:10.5539/elt.v8n9p40 URL: http://dx.doi.org/10.5539/elt.v8n9p40

\begin{abstract}
This paper presents a case study of students' perceptions and attitudes towards Blended Learning course in English at University of Bisha. The statement of problem that blended learning of English course annoys students at University of Bisha. Most of the students do not understand well the objectives of e learning through blended learning courses or mostly deal with the blackboard system "Learning Management System" (LMC). This paper identifies the perceptions and attitudes that blended learning provides to students' learning experiences as well as to investigate negative impressions in blended English courses from the learners' perception. This paper also outlines the concept of blended learning courses and e-learning from students' viewpoints. In this paper, the author conducted a survey through a questionnaire at University of Bisha, English department from eight levels of undergraduate program in both boys and girls colleges. There are (130) respondents enrolled in English department. The questionnaire was designed to measure the students' perceptions and attitudes towards BL. This study concludes that in general the students 'perceptions and attitudes towards BL were positive in terms of the three domains in the questionnaire. Moreover, students are encouraged to take responsibility for their own learning process. As well as learners can decide when and how to use the resources provided. This study also concludes that blended learning is as effective as face to face learning in developing and improving knowledge and skills. It reflects the students' negative impressions in some points as waste of time, easy cheating and social isolation...etc.
\end{abstract}

Keywords: attitudes blended learning course, learning, learners, and perceptions

\section{Introduction}

Use of technology in education has become necessary and inevitable, not a luxury because of its positive effects on the teaching and learning process. Recently, there has been much attention paid to the growing blended learning course in University of Bisha. Most of the current efforts have been focused on encouraging students to use blended courses. They got appropriate training sessions in how to use and apply all tools and activities in blackboard. The blended learning course is one of the important applications of using information and communication technology in the educational process. Blended learning course is the way which combines face to face and online learning. In Saudi Arabia, decision-makers, educational researchers, educators and the general public and particularly students are gaining awareness of the advantages of these technologies and are adopting them widely, though in some limited domains. University of BIsha is one of the universities in Saudi Arabia which promotes e-learning centers and e-learning communities. Some limited courses are compulsorily delivered asynchronously online in the form of blended learning. In King Khalid University (KKU), as well in University of Bisha there are three-level strategies courses adopted and implemented in e-learning. These three levels are as follow:

1) Supportive e-learning, which is a mandatory requirement for all faculty members. In this level, students take classes in traditional classrooms but can simultaneously use LMS (Blackboard program) to obtain information regarding their courses such as announcements, course syllabi, and information regarding instructors. Students are also able to share in discussions forums and encouraged to use e-mails.

2) Blended Learning, which is optional for faculty members. In this level, between $20 \%$ and $75 \%$ of the course content is delivered online through Blackboard (BB). 
3) Full e-learning, in which the course is delivered completely online.

University of Bisha has adopted supportive e-learning and blended learning levels of strategy learning, but right now the full e- learning has not been adopted.

\subsection{Objectives of the Study}

The objectives of the present study are:

1) To identify perceptions and attitudes of the students towards blended learning of English courses.

2) To investigate negative impressions about blended learning of English courses.

3) To outline concepts of Blended Learning of English courses and e-learning as students perceive them

\subsection{Literature Review}

In the previous studies investigated the effectiveness of the blended learning approach. They mostly reported that blended learning meets the educational needs of students such as satisfaction of learning, enhancing convenience and flexibility, achieving and improve language learning skills as well as to developing critical thinking skills. Some writers say there is students' satisfaction towards blended learning and enjoyable with this new method of teaching in general. Bendania (2011) is one of those who clarify positive attitudes and the factors related to attitudes; mainly experience, confidence, enjoyment, usefulness, intention to use, motivation and whether students had ICT skills were all correlated. Al Zumor (2013) cited by Aliweh (2011) also take a similar position, investigated Egyptian EFL students' learning styles and satisfaction with web-based materials. Findings of the study showed highly positive perceptions because of an array of benefits (e.g., usefulness, enjoyment, accessibility, convenience, and richness of resources). Moreover, students' gender had a significant effect on students' learning style preferences; it had no bearing on their satisfaction with web-based materials. Adas, D. and Wafa, A. (2011), similarity in his study approved that the students' attitudes toward Blended Learning were positive in terms of the process, ease of use and content. Moreover, this study reflected the students' internet and IT skills and interests due to Internet availability and accessibility. Alshwaih (2009) as well as reported that the students' attitudes and investigated the effects of a proposed blended learning towards the English language when teaching medical vocabulary to pre-med students in Arabian Gulf University. The findings did not show statistically significant differences regarding achievement or demonstrated a high degree of satisfaction with online unit. Some studies contacted with the viewpoints of students regarding blended learning. Akkoyunlu and Soylu (2006) is one of those who investigated the view of students regarding the Blended Learning environment. The results of the study revealed that the more students participated in the online discussion forums, the more they achieved and the more positive views they developed towards Blended Learning. Moreover, the study came up with the conclusion that both the face-to-face lectures and the online tasks contributed to the learning process. (Wing \& Khe, 2011). Edwards and Fritz (1997) also take a similar position, aimed to identify the students' viewpoints in the three teaching methods that rely on the technology, and the study was conducted on undergraduate students. The results of the study reported that e-learning is fun and interesting where students were able to learn educational concepts and apply them well, as reported by the students that the outcomes of e-learning materials (blended learning) were better than traditional materials. Other studies cleayifed some factors and effectiveness of using blended learning. Al-Harbi's (2010) is one of them who showed that e-learning acceptance is influenced by different factors. A student's attitude toward e-learning and students' decision to use e-learning are the most important factor in determining a student's intention to use e-learning, i.e., the influence of the important people around them. Although, perceived e-learning accessibility plays a role in shaping the students' behavioral intention regarding e-learning acceptance. Artino (2010) also take a similar position, found out the relation between personal factors and students' choice of instructional format. The results showed that students who preferred to enroll in online courses reported greater confidence and satisfaction in their ability to learn online than other students. Badawi (2009) similarity, investigated that the blended learning model was more effective than the traditional model in developing prospective teachers' pedagogical knowledge. Meanwhile, the rest of scholars in their studies showed that course system is more beneficial than traditional way and impact of teaching though blended learning or internet. In the same vein, Sauers and Walker (2004) found that students in a blended course indicated that their course system is more beneficial than the traditional face-to-face lectures. As well as Teeter (1997) identified the impact of teaching with the Internet on the students' motivation to learn and increase their ability to debate and resolve duties, the results indicated to increase students' motivation, and inform them of a lot of sources, and improve their ability to debate and solve homework. Behjat, Yamini and Bagheri (2012) showed that the Iranian tertiary education contexts that blending traditional classroom instruction and technology can help learners excel in their reading comprehension. 
From these studies we understand that students have satisfaction with blended learning, but they don't have sufficient exposure to computer technology in the classroom or out classroom. Furthermore, the students' viewpoints and ambiguous instruction and guidelines make students lost and disengaged. The mixed findings suggest that technology should be integrated appropriately and effectively within classrooms in order to improve and maximize students' learning outcomes. So this study posits the blended learning to reinforcement exercises and has positive pedagogical impact on them.

In the other hand, some studies have reported that students have their anxiety and confusion when interacting with online materials (Burgess, 2008; Baharun \& Porter, 2009).

\subsection{Definition of Blended Learning}

There are many educationists defined blended learning in a variety of ways for example: Hartman et al. (2007) defined blended learning as courses that combine face-to-face classroom instruction with online learning and reduced classroom contact hours (reduced seat time). Sands (2002) agreed with what Hartman said stating that, seat time is reduced and some of the course activities information transfer, exchange of ideas, testing, essay-writing, etc. are distributed throughout the semester. Chan (2008) identify that blended learning is "the ability to combine elements of classroom training, live and self-paced e-learning, and advanced supportive learning services in a manner that provides a tailored learning..." Blended learning allows students to dictate their path and pace through online technologies while being supervised within an educational setting face to face instruction. Environment conducive to both online learning and face to face instruction are emerging cross the educational system (Horn \& Staker, 2011). Blended learning has been described as a pedagogical approach that combines effectiveness and socialization opportunities of the classroom with the technologically enhanced active learning possibilities of the online environment (Dziuban, Hartman, \& Moskal, 2004). Whitelock and Jefts (2003) said clearly that blended learning has been depicted as an approach that combines traditional learning with web-based online approaches. In addition, Badawi, (2009, p. 15) defined blended learning as "a flexible approach that combines face-to-face learning activities with online learning practices that allow students to exchange collective and individual feedback and responses [in] four specific areas, namely, learner feedback, learner strategies, and alternative assessment synchronously or asynchronously".

To sum up, blended learning courses have some face-to-face class meetings, but also have some class sessions that are replaced with online instruction.

\subsection{Significance of the Study}

The significance of the study comes from the perceptions and attitudes of students about blended learning which helps teachers to evaluate the teaching-learning process. Yilmaz-Soylu $(2008$, p. 27) said that "The degree of learners' expectations, satisfaction, opinions or views on courses has played an important role in evaluating the effectiveness of learning processes". Moreover, when students perceive their experience as enjoyable, satisfying, and personally fulfilling, they tend to interact more, which results in enhanced learning". In addition, that Esani (2010) determined another important benefit of blended learning is that it saves time. And McCarthy \& Murphy (2010, p. 670) said that "Students would be able to complete programs in less time".

In the other side, both face-to-face and online teaching environments have their advantages; "A mixture of teaching and learning methods will always be the most efficient manner in which to support student learning because only then it is possible to embrace all the activities of discussion, interaction, adaptation and reflection, which are essential for academic learning" (Towndrow \& Cheers, 2003, p. 57). Al-Saleem et al. (2010) in his study investigated the effect of using blended learning on teaching English as a foreign language (EFL) on students' oral skills. The result of the study proved that blended learning enhanced significantly the EFL oral skills of the students of the experimental group due to the teaching procedures. This result is explained that blended learning exposed students to unlimited interaction with a language user, using sense of hearing, seeing and interacting. Also, the experimental groups were more interested in learning oral skills and that had a positive improvement in their achievements.

\section{Methodology}

This study used the descriptive method to study the different variables as many other studies. And the present research is a qualitative research that used the survey method to gather data information from respondents. To fulfill the objectives of the study the following procedures were undertaken.

\subsection{The Population}

The population of the study includes all students enrolled in Department of English (Boys - Girls) at the University of Bisha - Full semester in academic year 2015/2016. 


\subsection{Participants}

The participants consisted of a random sample of 130 ( 80 boys, 50 girls) students out of ( 326 boys students + 285 girls students $=611$ students) in 8 different levels of undergraduate students at the Department of English, College of Science and Arts (boys \& girls) University of Bisha.

\subsection{Data Collection Process}

Data required for this study was collected through questionnaire which includes 130 students. The questionnaire was distributed in the first term in the academic year 2015/2016.

\subsection{Instruments}

The survey forms included close-ended Likert scale statements (quantitative data). The scoring for the questionnaire was five Likert scale (Strongly Agree- Agree- Undecided- Disagree- Strongly Disagree). The data was collected using a questionnaire prepared after looking critically at the literature review related to this field. The questionnaire was developed to identify students' views on Blended Learning for English courses. Statements in the questionnaire were categorized into 3 main domains as follow:

- The items (1-12) identify the students' perceptions and attitudes of BL for English course.

- The items (13-24) address the negative impressions of BL for English courses from the students' perception.

- The items (25-36) are related to concepts of BL as students perceive them.

\subsection{Validity and Reliability of the Instruments}

The inter-rate approach was followed. The questionnaire was presented to some experts specialized from the department faculty members at Bisha University in order to ensure its validity and reliability and provided written feedback. According to their suggestions and comments, some items were changed to clarify the meaning. Some items were modified in a way that is more appropriate to the aim of the study. The reliability of the questionnaire has been determined using Cronbach's Alpha. The value of this questionnaire using SPSS was 0.79, which indicates a high level of internal consistency for the scale. Furthermore, the questionnaire was administrated to (30) students as a pilot study. It helped to go for few modifications, improvements and ensured the validity and reliability.

\subsection{Procedures}

There are many scientific procedures that are outlined as follows:

- Prepare the tool of the study with the help of previous studies.

- All the students who were registered in first term 2015/2016 were collected.

- A sample of the study was chosen randomly from the population of the study.

- The questionnaire was distributed to the students during their classes and then collected after that.

- The data of questionnaire were collected and tested for integrity and clarity.

- The results of questionnaire were analyzed by (SPSS program, 16.0) for final result and conclusions.

\section{Results and Discussion}

This study used the method of collecting personal data and questions. The personal information about the participants were related to student's level (1st - 8th), GPA(grade points average) (2-5), gender (male \& female), state their opinion about studying English courses as blended learning mode and they have got sufficient training in the use of blended learning. These five variables were expected to guide the respondents' perceptions and attitude regarding blended learning for English course and negative impressions. It is very important to constitute a wide picture about background of the participants. In this section, the researcher presents results of the study and also discusses their implications. In the following Table 1 highlights the personal information data and various variables of questions and answers: 
Table 1. Personal Information

\begin{tabular}{|c|c|c|c|c|c|c|c|c|c|}
\hline \multirow{2}{*}{$\begin{array}{l}\text { Level } \\
\text { Variable }\end{array}$} & \multicolumn{2}{|c|}{$\begin{array}{l}\text { Students' } \\
\text { level }\end{array}$} & \multicolumn{2}{|c|}{$\begin{array}{l}\text { Students' } \\
\text { GPA }\end{array}$} & \multicolumn{2}{|c|}{ Students' gender } & $\begin{array}{l}\text { Ss studied an English } \\
\text { course as Blended } \\
\text { Learning mode }\end{array}$ & \multicolumn{2}{|c|}{$\begin{array}{l}\text { Ss have got sufficient training } \\
\text { and guidance in the use of } \\
\text { Blended Learning }\end{array}$} \\
\hline & $1-4$ & $5-8$ & $2-3$ & $4-5$ & $\mathrm{M}$ & $\mathrm{F}$ & Yes & Yes & No \\
\hline Frequency & 42 & 88 & 77 & 53 & 80 & 50 & 61 & 43 & 87 \\
\hline percent & 32.3 & 67.7 & 59.2 & 40.8 & 61.5 & 38.5 & 46.9 & 33.1 & 66.9 \\
\hline
\end{tabular}

Table 1 shows the personal data with their percentage. The table explains the number of students from level 5-8 is higher than the number of students from (1-4). So the participants from higher levels are more than the participants from the lower levels. While the student's GPA in (2-3) gets more GPA than student's GPA in (4-5) and student's GPA in (2-3) got more marks in their studying rather than student's GPA (4-5). This study shows student's gender either male or female, that the number of male students is higher than the number of female students. This confirms the finding of Koohang's (2004) study regarding gender is that boys were more inclined to use the blended learning environment than girls. To answer the questions that determined if the students have studied English course as BL mode. The ratio of answering was almost the same (see Table 1). In the second questions that if the students have got sufficient training sessions and guidance in the use of BL. The answer in negation was ( 87 out of 130 with $66.9 \%$ ) said 'no'. It means that most of students did not get sufficient training and guidance in the use of BL.

The first domain, twelve items in the questionnaire explored students' perceptions and attitudes of BL for English course with the total mean of this domain is 3.27. (Blackboard activities give students' the chance to read) rated the highest a mean of (3.51) followed by the logically presentation for those activities with a mean of (3.48). Meanwhile, the clearance of blended learning tasks are the lowest rated a mean (2.95).

Table 2 presented the first domain about students' perceptions and attitudes of BL for English course. The detailed information regarding the questionnaire items (1-12) are presented below.

Table 2. Highlights students' perceptions and attitudes of BL for English course

\begin{tabular}{|c|c|c|c|c|c|c|c|c|c|c|c|}
\hline & \multicolumn{2}{|l|}{$\mathbf{S A}$} & \multicolumn{2}{|l|}{$\mathbf{A}$} & \multicolumn{2}{|l|}{ NS } & \multicolumn{2}{|l|}{$\overline{\mathbf{D A}}$} & \multicolumn{2}{|c|}{ SDA } & \multirow[t]{2}{*}{ Mean } \\
\hline & $\mathbf{N}$ & $\%$ & $\mathbf{N}$ & $\%$ & $\mathbf{N}$ & $\%$ & $\mathbf{N}$ & $\%$ & $\mathbf{N}$ & $\%$ & \\
\hline $\begin{array}{l}\text { 1. Blackboard activities are presented } \\
\text { logically }\end{array}$ & 23 & 17.7 & 54 & 41.5 & 24 & 18.5 & 20 & 15.4 & 9 & 6.9 & $3.48 \mathrm{~A}$ \\
\hline $\begin{array}{l}\text { 2. Blackboard activities give me the } \\
\text { chance to read }\end{array}$ & 27 & 20.8 & 51 & 39.2 & 23 & 17.7 & 19 & 14.6 & 10 & 7.7 & $3.51 \mathrm{~A}$ \\
\hline $\begin{array}{l}\text { 3. Blended Learning activities are } \\
\text { interactive }\end{array}$ & 18 & 13.8 & 42 & 32.3 & 31 & 23.8 & 26 & 20.0 & 13 & 10.0 & $3.20 \mathrm{~A}$ \\
\hline $\begin{array}{l}\text { 4. BL makes my English language skills } \\
\text { better }\end{array}$ & 23 & 17.7 & 47 & 36.2 & 32 & 24.6 & 22 & 16.9 & 6 & 4.6 & $3.45 \mathrm{~A}$ \\
\hline 5. BL is easy & 33 & 25.4 & 42 & 32.3 & 30 & 23.1 & 11 & 8.5 & 14 & 10.9 & $3.29 \mathrm{~A}$ \\
\hline 6. $\mathrm{BL}$ is collaborative & 19 & 14.6 & 44 & 33.8 & 34 & 26.2 & 19 & 14.6 & 14 & 10.9 & $3.27 \mathrm{~A}$ \\
\hline 7. BL courses are useful and interesting & 11 & 8.5 & 54 & 41.5 & 27 & 20.8 & 28 & 21.5 & 10 & 7.7 & $3.22 \mathrm{~A}$ \\
\hline $\begin{array}{l}\text { 8.BL enhances the interaction between } \\
\text { teachers and students }\end{array}$ & 32 & 24.6 & 35 & 26.9 & 22 & 16.9 & 28 & 21.5 & 13 & 10.0 & $3.35 \mathrm{~A}$ \\
\hline 9. BL tasks are clear & 16 & 12.3 & 31 & 23.8 & 33 & 25.4 & 31 & 23.8 & 19 & 14.6 & $2.95 \mathrm{NS}$ \\
\hline $\begin{array}{l}\text { 10. BL gives me enough time to do my } \\
\text { tasks }\end{array}$ & 23 & 17.7 & 39 & 30.0 & 34 & 26.2 & 23 & 17.7 & 11 & 8.5 & $3.31 \mathrm{~A}$ \\
\hline 11. I can always learn from Blackboard & 20 & 15.4 & 35 & 26.9 & 37 & 28.5 & 26 & 20.0 & 12 & 9.2 & $3.19 \mathrm{NS}$ \\
\hline $\begin{array}{l}\text { 12. I can learn from Blackboard in my } \\
\text { own style }\end{array}$ & 19 & 14.6 & 38 & 29.2 & 30 & 23.1 & 24 & 18.5 & 19 & 14.6 & $3.11 \mathrm{~A}$ \\
\hline Total mean & & & & & & & & & & & 3.27 \\
\hline
\end{tabular}

Question 1: It is observed that 54 (41.4\%) out of 130 respondents agreed that blackboard activities are presented logically. And then some of them about 24 (18.5\%) were undecided. But, 9 (6.9\%) were strongly disagree. Based 
on the descriptive statistics, mean of this item was (3.48) of the BB activities were presented logically.

Question 2: About half of the respondents are of opinion that 51 (39.2\%) concluded that the blackboard activities give (me) the chance to read. And about 27 (20.8\%) were strongly agree. Whereas $10(7.7 \%)$ of them were strongly disagree to this item. The mean is (3.52) of that $\mathrm{BB}$ activities give (me) the chance to read.

Question 3: $42(32.3 \%)$ of the respondents said (agree) that blended learning activities are interactive. And some of them around $31(23.8 \%)$ were undecided. But, $13(10.0 \%)$ of respondents were strongly disagree. The total mean of this item is (3.20) of blended learning activities are interactive.

Question 4: About half of respondents 47 (36.2\%) agreed that the blended learning makes my English language skills better. And $32(24.6 \%)$ were undecided it up to the mark and $6(4.6 \%)$ were strongly disagree. The mean of this item is (3.45).

Question 5: As can be seen $42(32.3 \%)$ of respondents reported agree that the blended learning is easy. Then around $33(25.4 \%)$ of respondents were strongly agree. While $11(8.5 \%)$ were disagree. Mean of the item of the blended learning is easy, was (3.29).

Question 6: It showed that respondents of 44 (33.8\%) agreed that blended learning is collaborative and some of respondents about $34(26.2 \%)$ were undecided. While 14 (10.8) were strongly disagree. The mean is (3.27) of the $\mathrm{BL}$ is collaborative.

Question 7: Most of respondents 54 (41.5\%) concluded that the BL courses are useful and interesting, besides 28 $(21.5 \%)$ disagreed but $10(7.7 \%)$ strongly disagreed. The mean is (3.22) of the BL courses are useful and interesting.

Question 8: About $35(26.9 \%)$ respondents agreed that $\mathrm{BL}$ enhances the interaction between teachers and students. Only $32(24.6 \%)$ were strongly agree. But $13(10 \%)$ were strongly disagree about that. The total mean of this item is (3.35) of BL enhances the interaction between teachers and students.

Question 9: It represented that 33 (25.4\%) of respondents undecided that the Blended Learning tasks are clear, whereas $31(23.8 \%)$ of them were disagree. while $16(12.3 \%)$ of respondents were strongly agreed. The total mean of this item is (2.95) of the Blended Learning tasks are clear.

Question 10: It revealed that 39 (30.0\%) out of 130 respondent agree that B L gives (me) enough time to do (my) tasks, besides $34(26.2 \%)$ of them showed undecided. But 11 (8.5\%) said strongly disagree. The mean is (3.31) of the B L gives (me) enough time to do (my) tasks.

Question 11: 37 (28.5.3\%) of respondents were undecided if they can always learn from blackboard. And then 35 $(26.9 \%)$ of them were agreed. But, $12(9.2 \%)$ were strongly disagree. The total mean of this item is (3.19) of blended learning activities are interactive.

Question 12: As can be seen 38 (29.2\%) of respondents agreed if they can learn from Blackboard in their own style. Then, some of respondents about $30(23.1 \%)$ were undecided. While 19 (14.6\%) of respondents in both were strongly agree and disagree. Mean of the item of that they can learn from Blackboard in their own style, was (3.11).

Table 2 shows that majority of the respondents expressed their positive attitude towards blended learning for English courses. This confirms the findings of some researchers that learners showed positive attitudes towards teaching and learning online. This is in consonant with some previous studies such as (Aliweh, 2011; Adas \& Wafa, 2011; Bendania, 2011; Akkoyunlu \& Soylu, 2006). Undoubted, there are some students expressed their opinion as disagreement concerning taking part in blended learning process as such.

This finding illustrates the students' satisfaction with BL as it enhanced to improve English language skills and helps them to make English learning collaborative, interactive and interesting. In addition, this reflects the interaction between teachers and students, and gives them enough time to do their tasks.

Table 3 follows the previous questionnaire items starting from (13-24). This domain is about negative impressions of blended learning for English course from students' perception. 
Table 3. Negative impressions of BL for English courses from students' perception

\begin{tabular}{|c|c|c|c|c|c|c|c|c|c|c|c|}
\hline & \multicolumn{2}{|l|}{ SA } & \multicolumn{2}{|l|}{ A } & \multicolumn{2}{|l|}{ NS } & \multicolumn{2}{|c|}{ DA } & \multicolumn{2}{|c|}{ SDA } & \multirow[t]{2}{*}{ Mean } \\
\hline & $\mathrm{N}$ & $\%$ & $\mathrm{~N}$ & $\%$ & $\mathrm{~N}$ & $\%$ & $\mathrm{~N}$ & $\%$ & $\mathrm{~N}$ & $\%$ & \\
\hline $\begin{array}{l}\text { 13.Slow internet connectivity is a problem } \\
\text { for BL }\end{array}$ & 53 & 40.8 & 41 & 31.5 & 15 & 11.5 & 10 & 7.7 & 11 & 8.5 & 3.88 \\
\hline $\begin{array}{l}\text { 14. My teachers do not reply my emails } \\
\text { quickly. }\end{array}$ & 20 & 15.4 & 50 & 38.5 & 32 & 24.6 & 18 & 13.8 & 10 & 7.7 & 3.40 \\
\hline 15. BL materials aren't well organized. & 26 & 20.0 & 31 & 23.8 & 36 & 27.7 & 25 & 19.2 & 12 & 9.2 & 3.26 \\
\hline $\begin{array}{l}\text { 16. The instructor isn't on time for all } \\
\text { activities }\end{array}$ & 20 & 15.4 & 28 & 21.5 & 39 & 30.0 & 29 & 22.3 & 14 & 10.8 & 3.08 \\
\hline 17. BL is frustrating to use. & 24 & 18.5 & 36 & 27.7 & 26 & 20.0 & 30 & 23.1 & 14 & 10.8 & 3.20 \\
\hline 18. BL is a waste of time. & 22 & 16.9 & 31 & 23.8 & 22 & 16.9 & 27 & 20.8 & 28 & 21.5 & 2.94 \\
\hline $\begin{array}{l}\text { 19. BL can lead students to cheating and } \\
\text { to other unethical practices }\end{array}$ & 25 & 19.2 & 28 & 21.5 & 22 & 16.9 & 29 & 22.3 & 26 & 20.0 & 2.98 \\
\hline 20. BL instructions' aren’t easy to follow. & 23 & 17.7 & 38 & 29.2 & 33 & 25.4 & 21 & 16.2 & 15 & 11.5 & 3.25 \\
\hline 21. I find BL difficult to do. & 23 & 17.7 & 42 & 32.3 & 29 & 22.3 & 25 & 19.2 & 11 & 8.5 & 3.32 \\
\hline 22. BL makes me socially isolated & 21 & 16.2 & 25 & 19.2 & 36 & 27.7 & 25 & 19.2 & 23 & 17.7 & 2.97 \\
\hline $\begin{array}{l}\text { 23. BL makes me need more face-to-face } \\
\text { interactions }\end{array}$ & 14 & 10.8 & 46 & 35.4 & 28 & 21.5 & 25 & 19.2 & 17 & 13.1 & 3.12 \\
\hline $\begin{array}{l}\text { 24. BL knowledge is less than classroom } \\
\text { knowledge }\end{array}$ & 27 & 20.8 & 30 & 23.1 & 38 & 29.2 & 23 & 17.7 & 12 & 9.2 & 3.28 \\
\hline
\end{tabular}

Question 13: Most of respondents about 53 (40.8\%) were strongly agreed that slow internet connectivity is a problem for BL, besides $41(31.5 \%)$ of respondents agreed but $10(7.7 \%)$ were strongly disagree. The mean of this item is (3.88) that showed slow internet connectivity is a problem for BL.

Question 14: Half of the respondents 50 (38.5\%) were agreed that (My) teachers do not reply (my) emails quickly. And 32 (24.6\%) were undecided. Whereas 10 (7.7\%) were strongly disagree to it. The mean of this item is (3.40) of that (My) teachers do not reply (my) emails quickly.

Question 15: 36 (27.7\%) of the respondents were undecided that BL materials aren't well organized. And then 31 $(23.8 \%)$ agreed. But, $12(9.2 \%)$ were strongly disagree. The total mean of this item is (3.26) of BL materials aren't well organized.

Question 16: About 39 (30.0\%) of respondents were undecided that the instructor isn't on time for all activities. And $29(22.3 \%)$ were disagree it up to the mark and $14(10.8 \%)$ were strongly disagree. The mean of this item is (3.08).

Question 17: It showed that respondents of $36(27.7 \%)$ agreed that BL is frustrating to use and $30(23.1 \%)$ of respondents were disagreed. While $14(10.8)$ were strongly disagree. The mean is (3.20) of that BL is frustrating to use.

Question 18: It observed that 31 (23.8\%) out of 130 respondents agreed that BL is a waste of time. And then 28 $(21.5 \%)$ were strongly disagree. But, $22(16.9 \%)$ both were strongly agree and undecided. Based on the descriptive statistics, mean of this item was (2.94) of that BL is a waste of time.

Question 19: As can be seen 29 (22.3\%) of respondents reported disagree that BL can lead students to cheating and to other unethical practices. Then $28(21.5 \%)$ were agreed. While $22(16.9 \%)$ were undecided. Mean of the item of BL can lead students to cheating and to other unethical practices, was (2.98).

Question 20: It revealed that 38 (29.2\%) out of 130 agreed that BL instructions' aren't easy to follow, besides 33 $(25.4 \%)$ of them showed undecided. But 15 (11.5\%) said strongly disagree. The mean is (3.25) of BL instructions' aren't easy to follow.

Question 21: About 42 (32.3\%) respondents agreed that I find BL difficult to do. Only 29 (22.3\%) were undecided. But $11(8.5 \%)$ were strongly disagree about that. The total mean of this item is (3.32) of I find BL difficult to do.

Question 22: It evident that 36 (27.7.3\%) of respondents were undecided if Blended Learning makes me socially 
isolated. And then 25 (19.2\%) of respondents were both agree and disagree of this item. But, 21 (16.2\%) were strongly disagree. The total mean of this item is (2.97) of BL makes me socially isolated.

Question 23: It represented that $46(35.4 \%)$ of respondents agreed that BL makes me need more face-to-face interactions, whereas $28(21.5 \%)$ were undecided. while $14(10.8 \%)$ were strongly agreed. The total mean of this item is (3.12) of BL makes me need more face-to-face interactions.

Question 24: As can be seen $38(29.2 \%)$ of respondents reported undecided that BL knowledge is less than classroom knowledge. Then 30 (23.1\%) were agreed about it. While $12(9.2 \%)$ were strongly disagree. Mean of the item of that BL knowledge is less than classroom knowledge, was (3.28).

A quick look at Table 3 indicates that there are some negative impressions towards blended learning for English courses from the viewpoints of students. The responses of the informants about negative expressions of blended learning are slow internet connectivity, teachers don't reply to emails, and lack of face to face interactions. Moreover, BL is difficult to do, knowledge isn't less than face to face knowledge, the instructions aren't easy to follow, frustrating to use. In addition, the negative points as to make social isolation, the materials of BL aren't well organized. Also the other drawbacks of negative expressions are wasting of time, lead students to cheating and other unethical practices.

This finding shows the students' negative expressions with Blended learning are more time consuming than traditional courses because of using communication via email or discussion board need more time than conducting face to face class. Other drawbacks of BL are slow internet connectivity, frustrating to use, face to face interaction and social isolation. This reflects also instructions' of BL aren't easy to follow and difficult to do.

Table 4 is about the concepts of BL from students' perception. The items of the questionnaire from (25-36) are in the third domains.

Table 4. The concepts of BL as students' perceive them

\begin{tabular}{|c|c|c|c|c|c|c|c|c|c|c|c|}
\hline & \multicolumn{2}{|l|}{ SA } & \multicolumn{2}{|l|}{$\mathrm{A}$} & \multicolumn{2}{|l|}{ NS } & \multicolumn{2}{|c|}{ DA } & \multicolumn{2}{|c|}{ SDA } & \multirow[t]{2}{*}{ Mean } \\
\hline & $\mathrm{N}$ & $\%$ & $\mathrm{~N}$ & $\%$ & $\mathrm{~N}$ & $\%$ & $\mathrm{~N}$ & $\%$ & $\mathrm{~N}$ & $\%$ & \\
\hline $\begin{array}{l}\text { 25. Online videos allow us to listen to } \\
\text { native speakers. }\end{array}$ & 34 & 26.2 & 50 & 38.5 & 14 & 10.8 & 20 & 15.4 & 12 & 9.2 & 3.57 \\
\hline 26. BL layout is attractive & 22 & 16.9 & 44 & 33.8 & 34 & 26.4 & 23 & 17.7 & 7 & 5.4 & 3.39 \\
\hline $\begin{array}{l}\text { 27. I find BL more convenient than face to } \\
\text { face learning. }\end{array}$ & 21 & 16.2 & 40 & 30.8 & 32 & 24.6 & 25 & 19.2 & 12 & 9.2 & 3.25 \\
\hline $\begin{array}{l}\text { 28. BL helps us to think in-depth about a } \\
\text { subject }\end{array}$ & 23 & 17.7 & 46 & 35.4 & 28 & 21.5 & 25 & 19.2 & 8 & 6.2 & 3.39 \\
\hline $\begin{array}{l}\text { 29. My personal devices (cell phone, mp3 } \\
\text { player, PDA) help me in learning. }\end{array}$ & 37 & 28.5 & 33 & 25.4 & 23 & 17.7 & 24 & 18.5 & 13 & 10.0 & 3.44 \\
\hline $\begin{array}{l}\text { 30. Social network applications (Facebook, } \\
\text { Twitter...other) help me in learning. }\end{array}$ & 36 & 27.7 & 47 & 36.2 & 18 & 13.8 & 16 & 12.3 & 13 & 10.0 & 3.59 \\
\hline 31. BL has motivated me to succeed. & 24 & 18.5 & 38 & 29.2 & 33 & 25.4 & 21 & 16.2 & 14 & 10.8 & 3.28 \\
\hline 32. We need BL training. & 33 & 25.4 & 42 & 32.3 & 30 & 23.1 & 11 & 8.5 & 14 & 10.8 & 3.53 \\
\hline $\begin{array}{l}\text { 33. My blended course experience has } \\
\text { helped me get more information. }\end{array}$ & 29 & 22.3 & 39 & 30.0 & 32 & 24.6 & 22 & 16.9 & 8 & 6.2 & 3.45 \\
\hline $\begin{array}{l}\text { 34. BL allows me to use different computer } \\
\text { programs. }\end{array}$ & 30 & 23.1 & 40 & 30.8 & 32 & 24.6 & 19 & 14.6 & 9 & 6.9 & 3.48 \\
\hline 35. BL helps me to master the material. & 18 & 13.8 & 34 & 26.2 & 36 & 27.7 & 31 & 23.8 & 11 & 8.5 & 3.13 \\
\hline $\begin{array}{l}\text { 36. BL helps me to be able to apply what I } \\
\text { have learned in the future (?) }\end{array}$ & 18 & 13.8 & 34 & 26.2 & 37 & 28.5 & 23 & 17.7 & 18 & 13.8 & 3.08 \\
\hline
\end{tabular}

Question 25: Half of the respondents $50(38.5 \%)$ were of opinion of agree that the online videos allow us to listen to native speakers. And $34(26.2 \%)$ were strongly agree. Whereas 12 (9.2\%) were strongly disagree. The mean of this item is (3.57) of that the online videos allow us to listen to native speakers.

Question 26: 44 (33.8\%) of the respondents agreed that BL layout is attractive. And then $34(26.4 \%)$ were 
undecided. But, 7 (5.4\%) were strongly disagree. The total mean of this item is (3.39) of BL layout is attractive.

Question 27: It observed that $40(30.8 \%)$ out of 130 respondents agreed that they find BL more convenient than face to face learning. And then 32 (24.6\%) were undecided. But, 12 (9.2\%) were strongly disagree. Based on the descriptive statistics, mean of this item was (3.35) of that they find BL more convenient than face to face learning.

Question 28: It showed that respondents of 46 (35.4\%) agreed that BL helps us to think in-depth about a subject and $28(21.5 \%)$ of respondents were undecided. While $8(6.2 \%)$ of respondents were strongly disagree. The mean is (3.39) of that BL helps us to think in-depth about a subject.

Question 29: It evident that 37 (28.5\%) of respondents were strongly agree if my personal devices (cell phone, $\mathrm{mp} 3$ player, PDA) help me in learning. And then 33 (25.4\%) of respondents were agree of this item. But, 13 $(10.0 \%)$ were strongly disagree. The total mean of this item was (3.44) about my personal devices (cell phone, $\mathrm{mp} 3$ player, PDA) help me in learning.

Question 30: About $47(36.2 \%)$ of respondents were agree that social network applications (Facebook, Twitter...other) help me in learning. And 36 (27.7\%) were strongly disagree it up to the mark and $13(10.0 \%)$ were strongly disagree. The mean of this item is (3.59).

Question 31: Some of respondents about 38 (29.2\%) agreed that BL has motivated (me) to succeed, besides 33 (25.4\%) of respondents were undecided but $14(10.8 \%)$ were strongly disagree. The mean of this item is (3.28) that showed BL has motivated (me) to succeed.

Question 32: It revealed that 42 (32.4\%) out of 130 agreed that we need BL training, besides 33 (25.4\%) of them showed strongly agree. But 11 (8.5\%) disagreed. The mean is (3.52) of we need BL training.

Question 33: As can be seen 39 (30.0\%) of respondents reported agree that my blended course experience has helped me get more information. Then $32(24.6 \%)$ were undecided. While $8(6.2 \%)$ were strongly disagree. Mean of the item of that my blended course experience has helped me get more information was (3.45).

Question 34: As can be seen 40 (30.8\%) of respondents reported agree that BL allows (me) to use different computer programs. Then $32(24.6 \%)$ were undecided. While $9(6.9 \%)$ were strongly disagree. Mean of the item of BL allows (me) to use different computer programs was (3.48).

Question 35: About $36(27.7 \%)$ respondents undecided that BL helps (me) to master the material. Only 34 (26.2\%) agreed. But 11(8.5\%) were strongly disagree. The total mean of this item was (3.13).

Question 36: It represented that 37 (28.5\%) of respondents undecided that BL helps me to be able to apply what I have learned in the future (?), whereas $34(26.2 \%)$ were agreed. while $18(13.8 \%)$ were both strongly agree and strongly disagree. The total mean of this item is (3.08) of BL helps me to be able to apply what I have learned in the future(?).

In relevance to the concept of Blended Learning from students' perception shows in Table 4. This domain presented that some respondents have their own perception about BL. These concepts from students' views help students to understand language through listening to native speakers, using social network applications, and thinking in depth about subject. The respondents also have their own views of BL as attractive of BL layout, BL is more convenient than face to face learning, and students need BL training. Moreover, the concepts which help students to use different computer programs, to motivate students to succeed, to use personal devices and to get more information have also been identified.

This finding presents the concept of Blended learning from students' perception. The views of students regarding blended learning are helping them to understand their subject material in English courses as watching online videos of native speakers and using both personal devices such as ( cell phone, mp3, PDA) and social network ( twitter, Facebook,...others). This study also reflects on the use of different computer programs, attractiveness and effectiveness of BL layout and students' needs for BL training.

\section{Conclusions}

The present study contributed to reveal the students' perception and attitude about BL for English course. The results of this study illustrate the students' satisfaction with Blended Learning as it enhance their English language skills and helps them to make English learning collaborative, interactive and interesting. Moreover, this reflects the interaction between teachers and students, and gives them enough time to do their tasks. So, students are encouraged to take responsibility for their own learning process and learners can decide when and how to use the resources provided. So, this study indicated that blended learning will be a more significant growth area than online learning. The results also show that the students' negative attitudes towards Blended learning were more 
related to BL being time consuming than traditional courses because of using communication via email or discussion board need more time than conducting face to face class. Other drawbacks of BL are slow internet connectivity created many problems for students. Moreover, some students consider it frustrating and socially isolated to use BL in comparison with face to face interaction. This reflects also instructions' of BL are not easy to follow and difficult to do. Furthermore, the views of students regarding blended learning are helping them to understand their subject material in English courses through watching online videos from native speakers and using both personal devices such as (cell phone, mp3, PDA) and social network (twitter, Facebook,...others). The students' views also let them be able to use different computer programs, attractive them to BL layout and students need BL training. The respondents also have their own views of BL is more convenient than face to face learning, and motivate students to succeed. Moreover, the students' views on BL help students to master the course (material) and to get more information. Blended Learning gives shy students chance to participate and share their opinions with their classmates on forum or other different way in blackboard.

\section{Recommendations and Implications}

In this study, it is worth to mention that BL is still in the developmental stage in University of Bisha. It needs more research and development that address types of BL from different aspects such as effective infrastructure and training of both instructors and learners with efficient skills in teaching and learning. Moreover, the researcher recommends another study in BL module as a new or modern method of teaching and learning of EFL in Saudi Universities.

Implication of this paper is based on the findings that emerged from the data analysis. It can be applied in university of Bisha as a single institution. The researcher suggests a research to adopt general methodology develop in BL in other than English course.

\section{References}

Abdul, W. Q. Al Z., Ismail, K. Al R., Eyhab, A. B. E., \& Farouq, H. A. Al-Rahman. (2013). EFL Students of a Blended Learning Environment: English Language Teaching, 6(10), 95-110. http://dx.doi.org/10.5539/elt.v6n10p95

Adas, D., \& Wafa, A. S. (2011). Students' perceptions towards blended learning environment using the OCC. An - Najah Univ. J. Res. (Humanities), 25(6), 1682-1710.

Akkoyunlu, B., \& Yilmaz, S. M. (2006). A study on students' views on Blended Learning environment. Turkish Online Journal of Distance Education, 7(3), 43-56.

Al-Harbi, K. A. (2010). E-learning in the Saudi tertiary education: Potential and challenges. Applied Computing and Informatics, 9, 31-46. http://dx.doi.org/10.1016/j.aci.2010.03.002

Artino Jr., A. R. (2010). Online or face to face learning? Exploring the personal factors that predict students' choice of instructional format. Internet and Higher Education, 13, 272-276. http://dx.doi.org/10.1016/j.iheduc.2010.07.005

Al-Saleem, B. I., Samadi, O. M., \& Tawalbeh, M. A. (2010). The effect of using blended learning on EFL Jordanian tenth grades student's oral skills (pp. 99-128). Proceedings of Education in the Era of Alternatives Conference. Yarmook University, Jordan, 20-22 April.

Alshwiah, A. A. S. (2009). The effects of a blended learning strategy in teaching vocabulary on premedical students' achievement, satisfaction and attitude toward English Language, M.A. Thesis, Arabian Gulf University.

Badawi, M. F. (2009). Using blended learning for enhanced EFL prospective teachers' pedagogical knowledge and performance. Conference Paper: Learning \& Language - The spirit of the Age. Cairo: Ain Shams University.

Baharun, N., \& Porter, A. (2009). Teaching statistics using a blended approach: integrating technology-based resources. In Same Places, different spaces. Proceedings ascilite Auckland 2009 (pp. 40-48).

Behjat, F., Yamini, M., \& Bagheri, M. S. (2012). Blended learning: A ubiquitous learning environment for reading comprehension. International Journal of English Linguistics, 2(1), 97-106 http://dx.doi.org/10.5539/ijel.v2n1p97

Bendania, A. (2011). Teaching and learning online: King Fahd university of Petroleum and Minerals (KFUPM) Saudi Arabia, case study. International Journal of Arts \& Sciences, 4(8), 223-241.

Burgess, J. (2008). Is a blended learning approach suitable for mature, part-time finance students? The Electronic 
Journal of e-Learning, 6(2), 131-138.

Chan, C. T., \& Koh, Y. Y. (2008). Different Degrees of blending benefit students differently: A Pilot Study. Proceedings of the EDU-COM 2008 International Conference, 19-21 November 2008. Retrieved from http://ro.ecu.edu.au/ceducom/7

Dziuban, C. D., Hartman, J. L., \& Moskal, P. D. (2004). Blended learning. Educause Research Bulletin, 7, 2-12.

Edwards, C., \& Fritz, J. (1997) Evaluation of three online delivery approaches. ERIC. Document Reproduction Service, 1997, No., ED430516.

Esani, M. (2010). Moving from face- to -face to online teaching. Clinical Laboratory Science, 23, 187-190.

Hartman, J., Dziuban, C., \& Moskal, P. (2007). Strategic initiatives in the online environment: opportunities and challenges, 15(3), 157-168.

Horn, M., \& Staker, H. (2011). The rise of blended learning. Mountain View, CA: Innosight institute, Inc. Retrieved from htpp://www.Innosightinstitute.org/innosight/wp-content/uploads/2014/04/the-Rise-of-12-Blended-Learning. pdf

Koohang, A. (2004). Students' perceptions toward the use of the digital library in weekly web-based distance learning assignments portion of a hybrid programme. British Journal of Educational Technology, 35, 617-626. http://dx.doi.org/10.1111/j.0007-1013.2004.00418.x

McCarthy, M. A., \& Murphy, E. A. (2010). Blended learning: Beyond initial uses to helping to solve real-world academic problems. Journal of College Education \& Learning, 7(6), 67-70.

Sands, P. (2002). Inside Outside, Upside Downside, Strategies for Connecting Online and Face-to-Face Instruction in Hybrid Courses. Teaching with Technology Today, 8(6). Retrieved April 9th, 2009, from http://www.uwsa.edu/ttt/articles/sands2.htm

Sauers, D., \& Walker, R. C. (2004). A comparison of traditional and technology-assisted instructional methods in the business communication classroom. Business Communication. Quarterly, 67, 430-442. http://dx.doi.org/10.1177/1080569904271030

Teeter, T. (1997). Teaching on the internet. Meeting the challenge of electronic earning, ERIC. Document Reproduction Service.

Towndrow, P., \& Cheers, C. (2003). Learning to communicate effectively in English through blended e-learning. Teaching and Learning, 24(1), 55-66.

Whitelock, D., \& Jefts, A. (2003). Editorial: Journal of Educational Media special issue on blended learning. Journal of Educational Media, 28(2-3), 99-100. http://dx.doi.org/10.1080/1358165032000177407

Wing, S. C., \& Khe, F. H. (2011). Design and evaluation of two blended learning approaches: Lessons learned. $\begin{array}{llll}\text { Australasian Journal of Educational Technology, 27(8), 1319-1337. } & \text {. }\end{array}$ http://dx.doi.org/10.1007/978-1-4614-2370-6_1

\section{Copyrights}

Copyright for this article is retained by the author(s), with first publication rights granted to the journal.

This is an open-access article distributed under the terms and conditions of the Creative Commons Attribution license (http://creativecommons.org/licenses/by/3.0/). 